\title{
The Effects of Propagation Techniques on Leaf Vascular Anatomy, Modulus of Elasticity, and Photosynthetic Traits in Micropropagated and Grafted Plants of the Dutch Elm Hybrid 'Dodoens'
}

\author{
Jaroslav Ďurkovič ${ }^{1}$, Ingrid Čaňová, and Lucia Javoříková \\ Department of Phytology, Technical University, 96053 Zvolen, Slovakia
}

\author{
Monika Kardošová \\ Department of Forest Protection and Game Management, Technical University, 96053 Zvolen, \\ Slovakia
}

Rastislav Lagaňa

Department of Wood Science, Technical University, 96053 Zvolen, Slovakia

Tibor Priwitzer

Forest Research Institute, National Forest Centre, 96092 Zvolen, Slovakia

Roman Longauer
Department of Silviculture, Mendel University, 61300 Brno, Czech Republic

Jana Krajňáková

Department of Biology, University of Oulu, 90014 Oulu, Finland

\begin{abstract}
AdDitional INDEX wORDs. rootstock, cell wall nanomechanics, stomatal conductance, chlorophyll fluorescence, Ulmus hybrid

Abstract. Understanding how plants are able to change their structural, physiological, and mechanical properties in response to various propagation methods can help to improve both their performance and their survival when transferred to field conditions. To identify changes between the routinely applied vegetative propagation techniques of in vitro micropropagation and splice grafting we assessed leaf performance for any differences in midrib vascular traits, nanomechanical properties of tracheary element cell walls, and photosynthetic traits in the dutch elm hybrid cultivar Dodoens (i.e., open-pollinated Ulmus glabra 'Exoniensis' $\times$ Ulmus wallichiana P39). The propagation techniques appear to have had a direct effect on a large portion of the vascular traits. In the micropropagated plants, the water-conducting area within the primary xylem tissue contained a significantly greater number of tracheary elements which suggests hydraulic safety. In the grafts, the water-conducting area contained a significantly smaller number of tracheary elements, in which the lumen areas were slightly larger than those of the micropropagated plants, resulting in a significantly higher size to number ratio which may indicate a fast and more effective water transport system. Quantitative nanomechanical mapping measurements from atomic force microscopy (AFM) revealed that the tracheary elements of the micropropagated plants formed stiffer cell walls quantified by the reduced Young's modulus of elasticity (MOE) than those of the grafts. The effect of the rootstock might contribute to the differences in vascular traits, as well as to the differences in cell wall stiffness and cell wall deformation observed between the stock types. The micropropagated plants were subjected to a more sensitive stomatal regulation of gas exchange resulting in the lower rates of net photosynthesis and transpiration. But the higher values of both instantaneous water-use efficiency (WUE inst and chlorophyll $a$ fluorescence yields found in the micropropagated plants indicate a higher acclimation capacity to stressful environmental conditions specifically for this stock type. Both stock types formed compact homogeneous clusters clearly separated from each other in the multivariate leaf trait analysis.
\end{abstract}

The initial elm breeding programs, launched in the Netherlands, were focused on the identification of resistant elm trees to dutch elm disease (DED) mostly from the native European species, U. glabra and Ulmus minor. Asian elms, particularly

Received for publication 15 Mar. 2016. Accepted for publication 22 Apr. 2016. This work was supported by funding from the Slovak scientific grant agency VEGA $(1 / 0149 / 15)$.

We thank D. Gömöry for statistical advice, M. Mamoňová for technical assistance with scanning electron microscopy, and E. Ritch-Krč for language revision.

${ }^{1}$ Corresponding author. E-mail: jaroslav.durkovic@tuzvo.sk.
U. wallichiana and Ulmus pumila, proved to be a useful additional source of DED-resistance genes (Santini et al., 2010; Smalley and Guries, 1993). A series of new dutch elm hybrid cultivars were released in the second half of the last century. Several hundred thousand grafted trees planted widely in Europe (Gerhold, 1970; Hiemstra et al., 2006) now show a varying degree of resistance to Ophiostoma novo-ulmi, the causative agent of the current DED pandemic (Brasier, 1991).

For many years, tolerant elm genotype selection and breeding has been the most successful strategy for elm recovery (Martín et al., 2015). Tissue culture techniques have been of 
great help for propagating DED-tolerant trees identified by elm breeding and conservation programs. Reliable protocols have been established for routine in vitro micropropagation of several elm species and commercial cultivars (Biroščíková et al., 2004; Conde et al., 2008; Corredoira et al., 2002; Fenning et al., 1993; Mezzetti et al., 1988). Thereby, in vitro culture techniques may contribute significantly to the efforts of tree improvement through existing germplasm conservation, in vitro selection for DED tolerance under highly controlled conditions, and the rapid distribution of new and improved cultivars (Ďrkovič et al., 2010; Eshita et al., 2000; Harvengt et al., 2004; Shukla et al., 2012). In addition, transgenic elms showing reduced DED symptoms have been regenerated (Newhouse et al., 2007) and small-scale field tests of transgenic elms have been established (Merkle et al., 2007).

Understanding the anatomical, physiological, and metabolic processes that allow plants to modify their phenotype in response to environmental conditions can help to improve both field performance and plant survival (Brito et al., 2009). Field assessment of gas exchange will give information about stomatal control of net photosynthetic rate, transpiration rate, and WUE (Benowicz et al., 2002; Durkovič et al., 2010). In addition, measurements of chlorophyll $a$ fluorescence yields can be used for assessing photochemical efficiency and photoinhibition in response to environmental stresses (Berger et al., 2007; Desotgiu et al., 2012; Zhao et al., 2015). Chlorophyll $a$ fluorescence competes for excitation energy with photochemistry (i.e., photosynthesis) and with nonradiative decay processes, thereby providing information for both processes (Carvalho et al., 2001).

The improved force-distance curve-based AFM techniques are a powerful tool to combine nanoimaging with quantitative mapping of physical, chemical, and biological properties. Recent developments in PeakForce quantitative nanomechanical mapping (PeakForce QNM; Bruker Nano Surfaces, Santa Barbara, CA) optimized this new AFM technique to the point that it enables high-resolution imaging of algae (Pletikapić et al., 2012) and woody plant cell walls (Durkovič et al., 2012, 2013; Ren et al., 2015), as well as fibrillar protein aggregates and native proteins (Pfreundschuh et al., 2014; Sweers et al., 2011). At the same time, with the imaging process, mapping measurements quantify the nanomechanical properties of material surfaces to nanonewton (or even piconewton) and nanometer resolution. The probe is usually oscillated at low frequencies to enable capturing and analyzing the individual force-distance curves each time the AFM tip taps on the sample's surface. The maps extracted from arrays of forcedistance curves provide crucial information on the nanomechanical properties of biological systems. The mechanical properties of the cellular microenvironment, notably its rigidity and stiffness, possess a regulatory role for a variety of cellular responses including adhesion, migration, shape, and division (Dufrêne et al., 2013; Janmey et al., 2009). Determination of the nanomechanical attributes of plant cell walls is of great importance for evaluating both the effects of hybridization and the results of plant breeding. Thus for the cell walls of xylem tissue, quantifications of MOE, adhesion, and cell wall deformation play a key role in the assessment of the material stiffness, toughness, and its adhesive properties (Ďurkovič et al., 2012, 2013).

Previous studies have revealed that the dutch elm hybrid 'Dodoens', a tree appreciated in cities and rural landscapes, shows a tolerance to the current prevalent strain of DED, O. novo-ulmi ssp. americana $\times$ novo-ulmi (Durkovič et al., 2013, 2014). Phenotypic expressions for the leaf and branch hydraulic, anatomical and morphological traits have revealed a constitutive strategy of defense for their possible role in DED tolerance (Plichta et al., 2016). The effects of propagation techniques on cell wall chemistry and wood anatomy of 'Dodoens' plants were assessed in our recent study (Ďrkovič et al., 2015). Here, we focused on changes in the leaf midrib vascular, nanomechanical, and ecophysiological traits with respect to the propagation technique. The objectives for this study were 1) to determine whether routinely applied vegetative propagation techniques that maintain true types of elm genotypes tolerant to DED (i.e., in vitro micropropagation vs. widely used grafting of past decades) would affect the indicators of leaf vascular architecture, gas exchange, and chlorophyll $a$ fluorescence yields; 2) to identify the differences between the examined stock types with respect to the nanomechanical properties of tracheary element cell walls, to reveal any mechanical advantages for either stock type when using multiparametric quantitative imaging of force-distance curve-based nanomechanical mapping; and 3) to find possible correlations among vascular, nanomechanical, and ecophysiological traits that could contribute to the maximum physiological leaf performance of 'Dodoens' plants in relation to the technique of propagation.

\section{Materials and Methods}

Plant material, study site, and sampling. The experiments were conducted on clonally micropropagated and grafted plants of the dutch elm hybrid cultivar Dodoens, which has shown a tolerance to an aggressive isolate $\mathrm{M} 3$ of $O$. novo-ulmi ssp. americana $\times$ novo-ulmi (Ďurkovič et al., 2013, 2014). The procedure of in vitro micropropagation through axillary and adventitious shoot formation has previously been described in detail (Krajňáková and Longauer, 1996). The grafted plants were obtained through splice grafting which consisted of joining a 'Dodoens' scion onto the stem of a DED-tolerant $U$. pumila 'Puszta' rootstock to reduce the possibilities of DED transmission in the soil by root graft connections (Green et al., 1985). Grafting of scions onto rootstock was performed $2 \mathrm{~cm}$ upward from the root-stem junction, and the scions used for both grafting and in vitro culture establishment originated from identical donor plants. Three-year-old micropropagated and grafted plantlets of uniform size were selected and then planted in the experimental field plot at Banská Belá, Slovakia (lat. $48^{\circ} 28^{\prime} \mathrm{N}$, long. $18^{\circ} 57^{\prime} \mathrm{E}$, altitude $590 \mathrm{~m}$ ). No postplanting treatments such as irrigation and fertilization were applied. The climate and soil conditions of the study site were described previously (Ďurkovič et al., 2015). The experiments were conducted on five plants per stock type unaffected by DED and chosen randomly to remove any positional effects in the field. Measurements were performed on fully expanded leaves in the tenth growing season following planting. Scanning electron microscopy images of the plant leaf material used in this study are presented in Fig. 1A-D.

LeAF HISTOLOGY AND MIDRIB VASCUlar TRAITS. Midrib sections $(0.4 \times 0.4 \mathrm{~cm})$, excised from the leaf base, were fixed in $5 \%(\mathrm{v} / \mathrm{v})$ glutaraldehyde in a $0.1 \mathrm{M}$ cacodylate buffer at $\mathrm{pH}$ 7.0, dehydrated in ethanol and propylene oxide, and embedded in Spurr embedding medium (Ďurkovič et al., 2013). 


\section{Micropropagated}

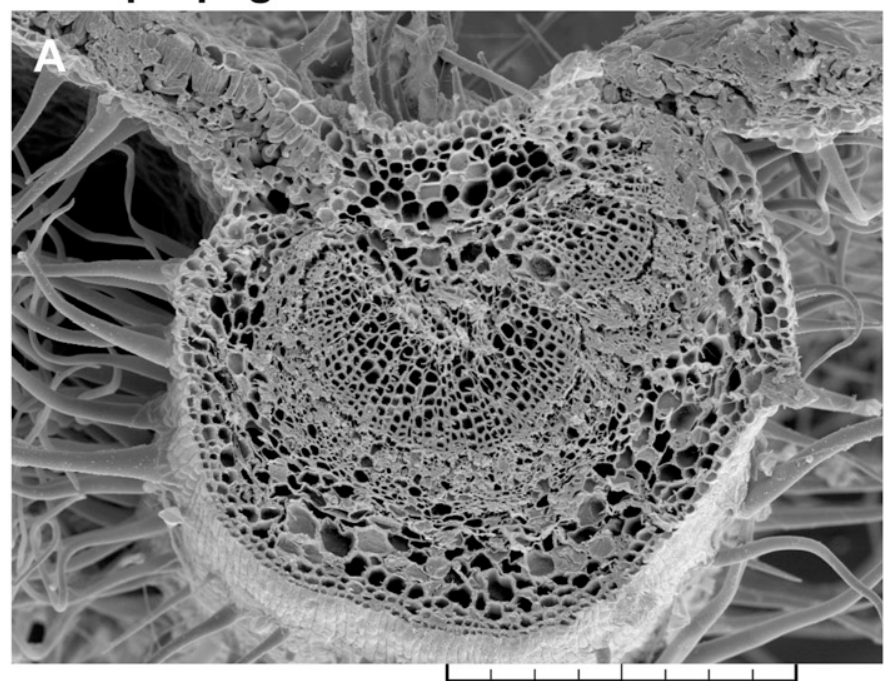

\section{Grafted}

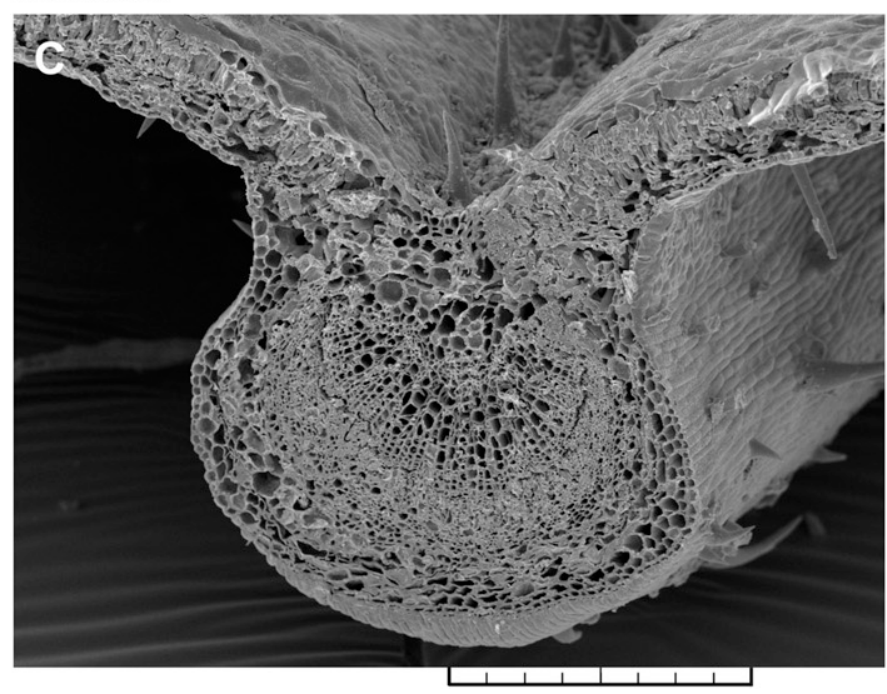

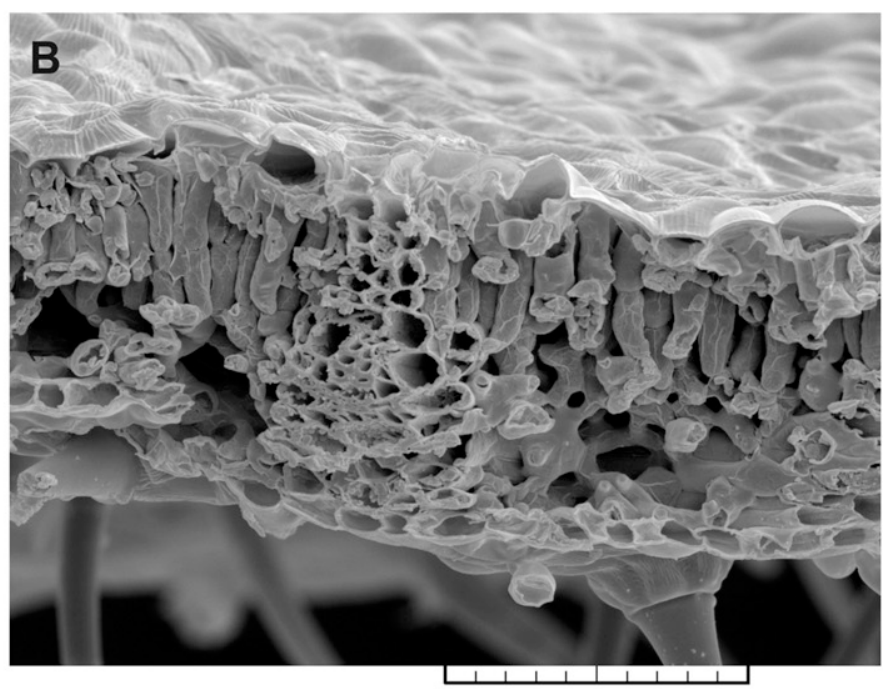

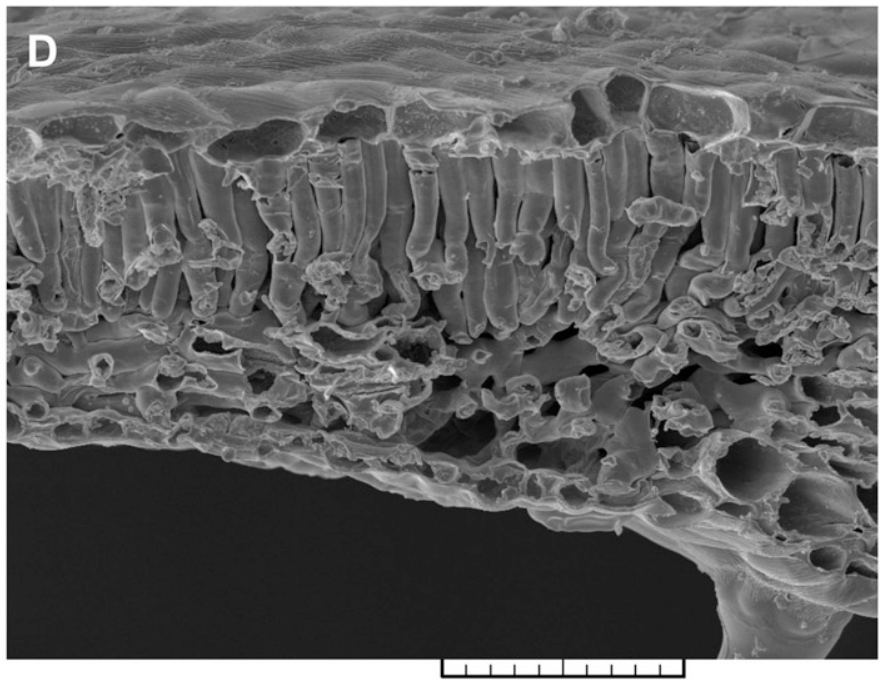

Fig. 1. Scanning electron microscope images of leaf samples collected from the micropropagated plants and the grafts of the dutch elm hybrid 'Dodoens'. (A, C) Leaf midrib and primary xylem area, cross-section (scale bars $=400 \mu \mathrm{m})$. (B, D) Mesophyll tissue, cross-section $(\mathrm{scale}$ bars $=100 \mu \mathrm{m})$.

Cross-sections, $\approx 1.5 \mu \mathrm{m}$ thick, were cut using an automated rotary microtome (RM2255; Leica Biosystems, Nussloch, Germany) with glass knives, and stained with toluidine blue and basic fuchsin. Sections were observed using a light microscope (BX50F; Olympus Europa, Hamburg, Germany). The thickness of the leaf, mesophyll, palisade, and spongy parenchyma was measured using the NIS-Elements AR 3.0 image analysis software (Laboratory Imaging, Prague, Czech Republic). Measurements were performed on five sun leaves per plant, one section per leaf, two measurements per section (on the left side and on the right side from the leaf midrib).

Vascular characteristics of the leaf midrib primary xylem; i.e., tracheary element lumen area $(A)$ and tracheary element densities $(N)$ per $0.1 \mathrm{~mm}^{2}$ of the primary xylem area, were determined using the NIS-Elements AR 3.0 image analysis software (Laboratory Imaging). The additional indicators of leaf vascular architecture such as tracheary element lumen fraction $(F=A \times N)$ and the tracheary element size:number ratio
$(S=A / N)$ were calculated as described in Zanne et al. (2010). Total relative conductivity (RC) per $0.1 \mathrm{~mm}^{2}$ of the primary xylem area was calculated as the sum of individual RCs divided by the area of a cross-section of primary xylem (Durkovič et al., 2012), whereas the individual RC was calculated as the fourth power of the equivalent circle diameter of the tracheary element lumen (Zimmermann, 1983). Lignin autofluorescence in cell walls of elements was detected by excitation at $360 \mathrm{~nm}$ using a barrier filter with a transmission cutoff at $470 \mathrm{~nm}$, and photographed using a fluorescence microscope (DM4000 B; Leica Microsystems, Wetzlar, Germany) equipped with a digital color camera (DFC490; Leica Microsystems). Measurements were performed on five sun leaves per plant, one section per leaf midrib, one measurement per section.

MULTIPARAMETRIC QUANTITATIVE NANOMECHANICAL MAPPING AND CELL WALL NANOMECHANICS. Midrib sections $(0.4 \times 0.4 \mathrm{~cm})$, excised from the leaf base, were fixed in $5 \%(\mathrm{v} / \mathrm{v})$ glutaraldehyde in a $0.1 \mathrm{M}$ cacodylate buffer at $\mathrm{pH} 7.0$, dehydrated through 


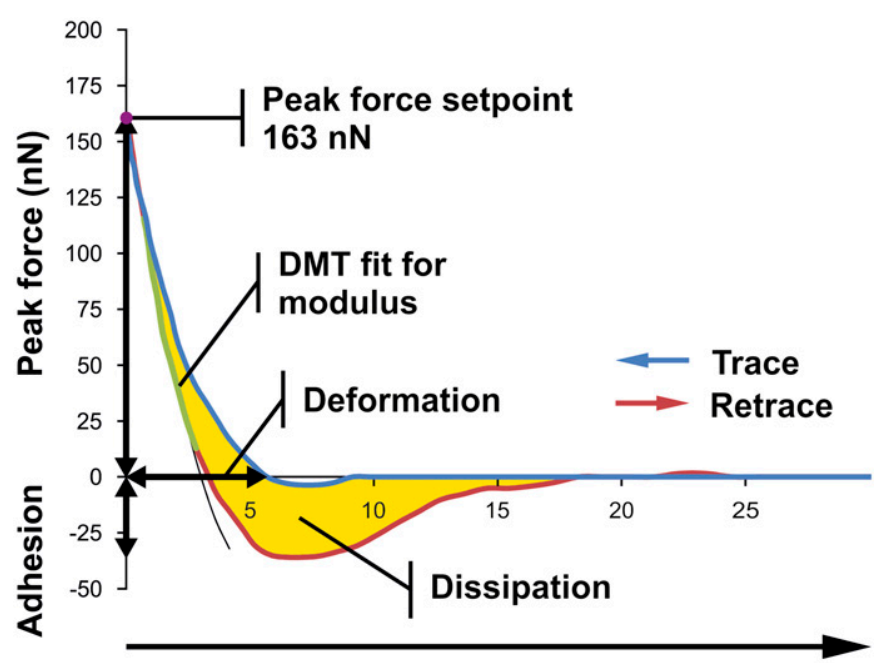

Tip-sample separation $(\mathrm{nm})$

Fig. 2. Basic principles illustrating how the different nanomechanical properties are extracted from the force-distance curve using multiparametric quantitative nanomechanical mapping measurements. The image shows a typical forcedistance curve for the tracheary element cell wall in the dutch elm hybrid 'Dodoens'. The adhesion is the vertical distance between the base line and the lowest portion of the retraction curve. The deformation is the horizontal distance between the contact point and the turn-away point (representing maximum indentation at peak force setpoint). The reduced Young's modulus of elasticity can be extracted by extrapolating the initial portion of the retraction curve after the contact point using the Derjaguin-Muller-Toporov model fit. The energy dissipation can be calculated by integrating the area between the two curves.

Table 1. Leaf midrib vascular traits in the dutch elm hybrid 'Dodoens'.

\begin{tabular}{lccc}
\hline & \multicolumn{2}{c}{ Stock type } & \\
\cline { 2 - 3 } & \multicolumn{2}{c}{ Micropropagated } & Grafted \\
\cline { 2 - 3 } Trait $^{\mathrm{z}}$ & \multicolumn{2}{c}{$($ mean $\pm \mathrm{SE})$} & \multicolumn{1}{c}{$P$ value } \\
\hline$A\left(10^{-5} \mathrm{~mm}^{2}\right)$ & $7.41 \pm 0.42$ & $7.93 \pm 0.34$ & $0.0709^{\text {Ns }}$ \\
$N\left(\right.$ no. $\left./ 0.1 \mathrm{~mm}^{2}\right)$ & $597 \pm 33$ & $429 \pm 20$ & $0.0001^{* * *}$ \\
$F\left(10^{-3} \mathrm{~mm}^{2}\right)$ & $41.8 \pm 1.3$ & $33.1 \pm 0.9$ & $0.0001^{* * *}$ \\
$S\left(10^{-7} \mathrm{~mm}^{4}\right)$ & $1.42 \pm 0.17$ & $1.97 \pm 0.16$ & $0.0043^{* *}$ \\
RC $\left(10^{-6} \mathrm{~mm}^{4}\right)$ & $6.90 \pm 0.47$ & $6.66 \pm 0.40$ & $0.9872^{\text {Ns }}$
\end{tabular}

${ }^{\mathrm{z}} A=$ tracheary element lumen area; $N=$ number of tracheary elements per $0.1 \mathrm{~mm}^{2}$ of the primary xylem area; $F=$ tracheary element lumen fraction; $S=$ tracheary element size:number ratio; RC = relative conductivity per $0.1 \mathrm{~mm}^{2}$ of the primary xylem area.

NS, **, ***Nonsignificant or significant at $P<0.01$ or 0.001 , respectively, based on nested analysis of variance.

a gradient series of ethanol, cleared with xylene, and embedded in paraffin (Durkovič and Mišalová, 2009). Cross-sections, $\approx 15 \mu \mathrm{m}$ thick, were cut using a retracting base sledge microtome (series 8000; Bright Instruments, Luton, UK), deparaffinized in xylene, mounted on circular glass slides (11 $\mathrm{mm}$ diameter) coated with (3-aminopropyl)triethoxysilane, and allowed to air dry in sterile petri dishes. Quantitative nanomechanical mapping measurements were done using a MultiMode 8 atomic force microscope (Bruker Nano Surfaces) with a Nanoscope V controller (Bruker Nano Surfaces). Cell walls of tracheary elements were tapped by silicon cantilevers (MPP-13120, model TAP525A; Bruker AFM Probes, Camarillo, CA) with a spring constant between 102.3 and $136.2 \mathrm{~N} \cdot \mathrm{m}^{-1}$, deflection sensitivity between 51.1 and
$52.8 \mathrm{~nm} \cdot \mathrm{V}^{-1}$, and resonance frequency between 510.1 and $514.9 \mathrm{kHz}$, at $25^{\circ} \mathrm{C}$ and ambient air pressure. Before each measurement, the actual tip end radius and geometry were controlled using a commercial test grating (TGT1; NT-MDT, Zelenograd, Russia) for three-dimensional visualization of the scanning tip. Quantitative nanomechanical mapping measurements of the reduced Young's MOE, adhesion, deformation, and energy dissipation were performed at low approach tip velocities of $0.46-0.48 \mu \mathrm{m} \cdot \mathrm{s}^{-1}$. To achieve accurate and reliable calculations of MOE, a sufficient sample deformation of at least $2 \mathrm{~nm}$ was ensured by adjusting the peak force setpoint to $163 \mathrm{nN}$ (Fig. 2). Measurements were performed on two sun leaves per plant, four cell walls of tracheary elements per leaf midrib, one measurement per cell wall.

AFM DATA PROCESSING OF MOE AND ADHESION. The initial data of the reduced Young's MOE, coming from the quantitative nanomechanical mapping (represented by $256 \times 256$ matrices), were analyzed by NanoScope Analysis software, version 1.40r2 (Bruker AXS, Santa Barbara, CA), which uses the Derjaguin-Muller-Toporov (DMT) model (Derjaguin et al., 1975). For the calculation of MOE, the DMT model accounts for adhesion by fitting the retract curve close to the contact point according to the following equation:

$$
F_{\mathrm{TIP}}-F_{\mathrm{ADH}}=\frac{4}{3} \mathrm{MOE} \sqrt{R\left(d-d_{0}\right)^{3}}
$$

where $F_{\mathrm{TIP}}-F_{\mathrm{ADH}}$ is the force on the tip cantilever relative to the adhesion force, $R$ is the actual tip end radius, and $d-d_{0}$ is the deformation of the sample cell wall. The raw data of MOE were subsequently imported into the MATLAB software, version 7 (MathWorks, Natick, MA). A slippery effect on the steep surface topography strongly influences the measurement of MOE (Durkovič et al., 2012, 2013). Thus, the height gradient was calculated for each image pixel. Values corresponding to "steep" points, where surface slope exceeded more than $20^{\circ}$, were not used.

In addition, as the adhesion pull-off force is influenced by the tip end radius and surface energy (Fischer-Cripps, 2011), the raw data of adhesion were normalized to the reference tip end radius of $100 \mathrm{~nm}$ (Amitay-Sadovsky et al., 2002). Adhesion at the reference tip end radius $\left(\mathrm{ADH}_{\mathrm{ref}}\right)$ of the tracheary element cell wall was calculated according to the following equation:

$$
\mathrm{ADH}_{\mathrm{ref}}=\mathrm{ADH}-\alpha\left(R-R_{\mathrm{ref}}\right)
$$

where ADH is adhesion pull-off force, $\alpha$ is the slope of an adhesion-tip end radius regression line, $R$ is the actual tip end radius, and $R_{\text {ref }}$ is the reference tip end radius of $100 \mathrm{~nm}$.

GaS EXCHANGE. An open portable photosynthesis system with an infrared gas analyser (LI-6400 XTR; LI-COR, Lincoln, $\mathrm{NE}$ ) was used for in situ gas exchange measurements. Net photosynthetic rate $\left(P_{\mathrm{N}}\right)$, transpiration rate $(E)$, stomatal conductance $\left(g_{\mathrm{S}}\right)$, and intercellular $\mathrm{CO}_{2}$ concentration $\left(C_{\mathrm{i}}\right)$ were measured under a saturating photosynthetic photon flux density of $1200 \pm 5 \mu \mathrm{mol} \cdot \mathrm{m}^{-2} \cdot \mathrm{s}^{-1}$ and an ambient $\mathrm{CO}_{2}$ concentration of $370 \pm 5 \mu \mathrm{mol} \cdot \mathrm{mol}^{-1}$ using the $6400-08$ standard leaf chamber with the 6400-02B light-emitting diode red/blue light source (LI-COR). WUE $\mathrm{W}_{\text {inst }}$ was calculated as the ratio of $P_{\mathrm{N}}$ to $E$ (Campbell et al., 2005). During measurements, microclimatic conditions inside the assimilation chamber were kept constant (leaf temperature $21 \pm 1{ }^{\circ} \mathrm{C}$, air relative humidity $70 \% \pm 5 \%$ ). The vapor pressure deficit ranged from 0.8 to $1.3 \mathrm{kPa}$. 

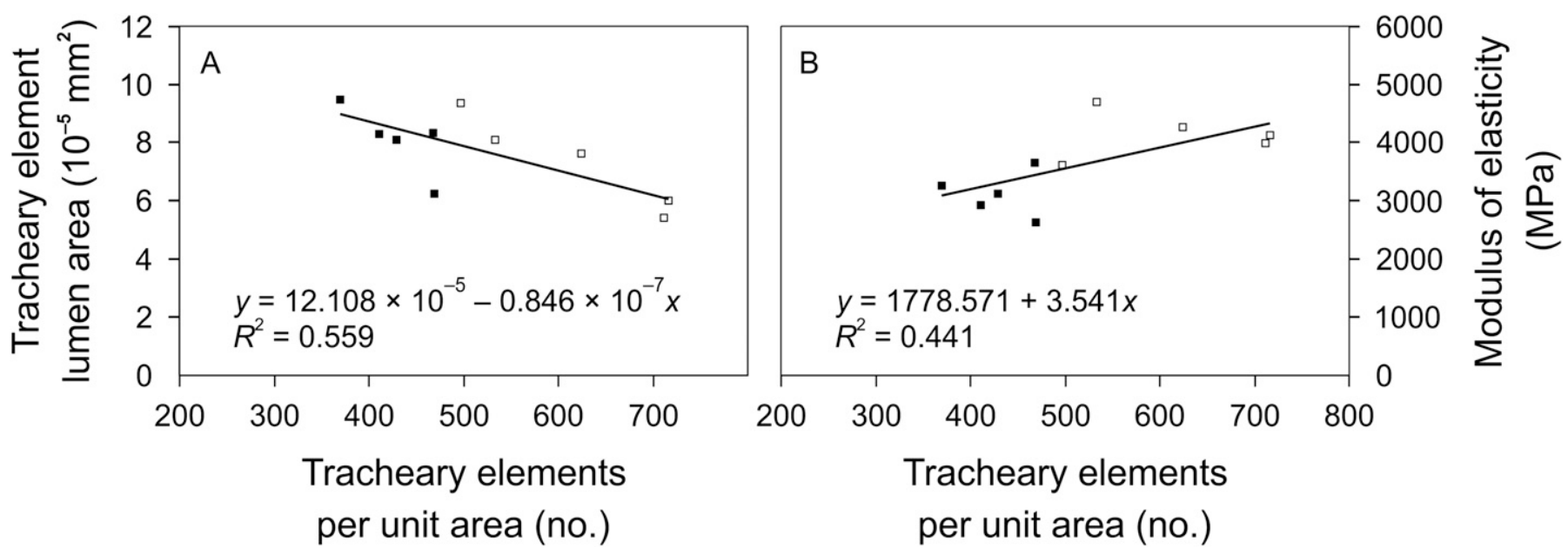

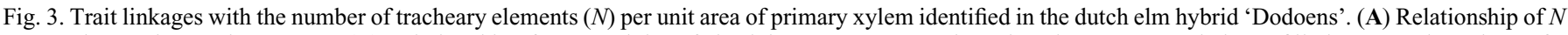
to tracheary element lumen area. (B) Relationship of $N$ to modulus of elasticity. Open squares show the micropropagated plants, filled squares show the grafts $(\mathrm{n}=10)$.

Table 2. Nanomechanical traits of tracheary element cell walls of the dutch elm hybrid 'Dodoens'.

\begin{tabular}{|c|c|c|c|}
\hline \multirow[b]{3}{*}{ Trait $^{z}$} & \multicolumn{2}{|c|}{ Stock type } & \multirow[b]{3}{*}{$P$ value } \\
\hline & Micropropagated & Grafted & \\
\hline & \multicolumn{2}{|c|}{$($ mean $\pm \mathrm{SE})$} & \\
\hline$\overline{\mathrm{MOE}}(\mathrm{MPa})$ & $4,144 \pm 187$ & $3,067 \pm 182$ & $0.0002 * * *$ \\
\hline $\mathrm{ADH}_{\mathrm{ref}}(\mathrm{nN})$ & $16.94 \pm 0.47$ & $17.61 \pm 1.13$ & $0.3219^{\mathrm{Ns}}$ \\
\hline $\operatorname{DEF}(\mathrm{nm})$ & $2.52 \pm 0.09$ & $2.29 \pm 0.08$ & $0.0446^{*}$ \\
\hline DIS $(e V)$ & $1,893 \pm 132$ & $2,118 \pm 157$ & $0.2716^{\mathrm{Ns}}$ \\
\hline
\end{tabular}

${ }^{\mathrm{z}} \mathrm{MOE}=$ reduced Young's modulus of elasticity; $\mathrm{ADH}_{\mathrm{ref}}=$ adhesion at the reference tip end radius of $100 \mathrm{~nm}$; DEF = deformation; DIS = energy dissipation.

NS, *, ***Nonsignificant or significant at $P<0.05$ or 0.001 , respectively, based on nested analysis of variance.

Measurements were performed on six sun leaves per plant, five measurements per leaf.

ChLOROPHYLl FLUORESCENCE AND CHLOROPHYLL CONTENT. Chlorophyll $a$ fluorescence yields were measured on sunexposed leaves using a portable fluorometer (Plant Efficiency Analyser; Hansatech Instruments, Kings Lynn, UK). Leaves were kept for $30 \mathrm{~min}$ under leaf clamps for dark adaptation. After the initial measurement of dark-adapted minimal fluorescence $\left(F_{0}\right)$, leaves were exposed to a saturating irradiance of $2100 \mu \mathrm{mol} \cdot \mathrm{m}^{-2} \cdot \mathrm{s}^{-1}$ for $1 \mathrm{~s}$ to measure the maximal fluorescence of dark-adapted foliage $\left(F_{\mathrm{m}}\right)$. Variable fluorescence $\left(F_{\mathrm{v}}\right)$ was calculated as $F_{\mathrm{v}}=F_{\mathrm{m}}-F_{0}$, and the variables such as maximum photochemical efficiency of photosystem II $\left(F_{\mathrm{v}} / F_{\mathrm{m}}\right)$, variableto-initial fluorescence ratio $\left(F_{\mathrm{v}} / F_{0}\right)$ and potential electron acceptor capacity of photosystem II - "area" (i.e., area above the induction curve between $F_{0}$ and $F_{\mathrm{m}}$ ) were determined. Measurements were performed on ten sun leaves per plant, two measurements per leaf (one per adaxial surface and one per abaxial surface).

Relative chlorophyll content was estimated with a portable chlorophyll meter (CL-01; Hansatech Instruments) and the results were expressed as the chlorophyll index (CHLI) (Cassol et al., 2008). Measurements were performed on seven sun leaves per plant, three measurements per adaxial leaf surface.
Statistical analysis. Data were analyzed by nested analysis of variance (plants were nested in stock types). The stock types were considered a fixed effect factor, whereas the plants were considered a random effect factor. The Pearson correlation coefficients were calculated for the selected trait-trait relationships. The correlations were considered significant if $P<0.05$. Multivariate associations among 22 leaf traits were analyzed using a principal component analysis (PCA) to describe patterns of covariation among the vascular, nanomechanical, and ecophysiological traits.

\section{Results and Discussion}

Differences in vascular traits. Significant differences were found between the stock types for a majority of leaf midrib vascular traits (Table 1). Both stock types employed different vascular anatomies. The micropagated plants showed higher values for the trait $N$, and also for the trait $F$ which measures the relative amount of water transport space. The grafts reached higher values for the trait $S$ which measures variation in the vessel composition within the water transport space. In the micropropagated plants, the water-conducting area within the primary xylem tissue contained a significantly greater number of tracheary elements which suggests hydraulic safety (driven by embolism avoidance) (Zanne and Falster, 2010). In the grafts, the water-conducting area contained a significantly smaller number of tracheary elements, in which the lumen areas were slightly larger than those of the micropropagated plants. This difference in the leaf vascular anatomy of the grafts was also supported by a higher value for trait $S$, which may indicate a fast and more effective water transport system (Zanne and Falster, 2010) as the water flows more easily through fewer larger tracheary elements than through a large number of smaller ones. However, the performances in RC per $0.1 \mathrm{~mm}^{2}$ of the primary xylem area between the stock types were not significantly different. This suggests that a relative trade-off was achieved between a couple of vascular architecture indicators, $A$ and $S$ on one side and $N$ and $F$ on the other side. The traits $A$ and $N$, which are the primary indicators of vascular anatomy, also showed a significant negative correlation with each other $(r=-0.75, P=0.013)$. Measurements of $N$ explained 


\section{Micropropagated}

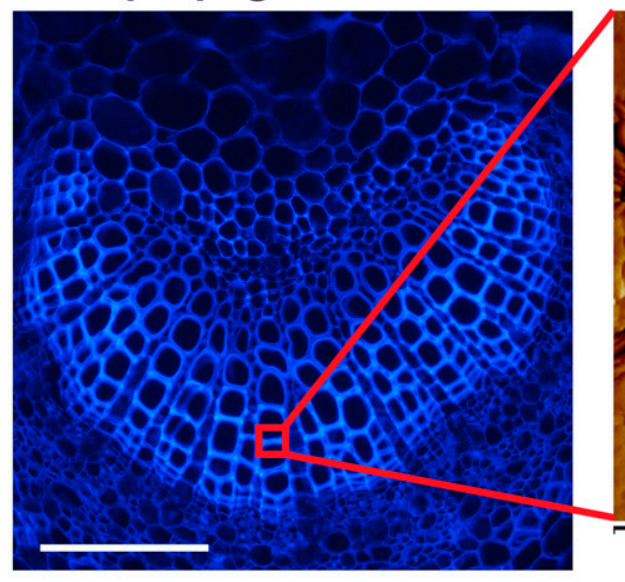

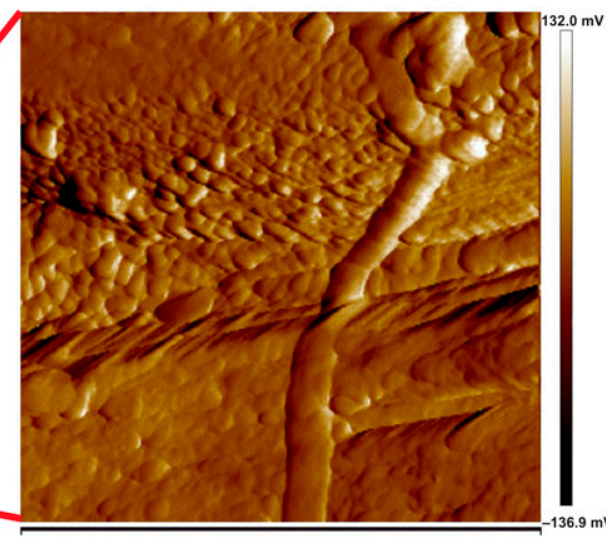

Peak force error

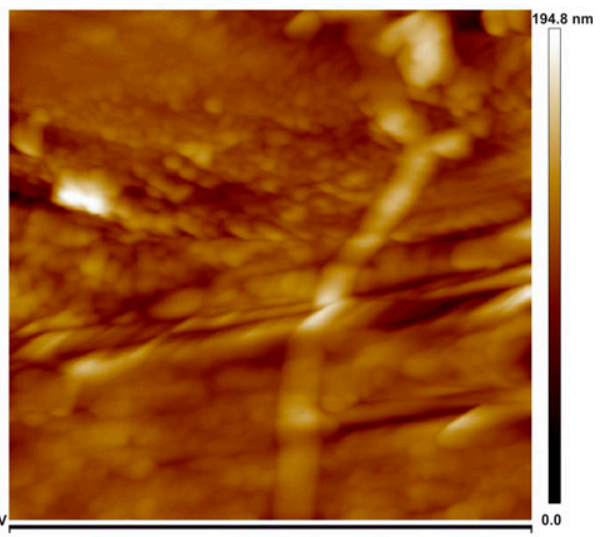

Height

\section{Grafted}

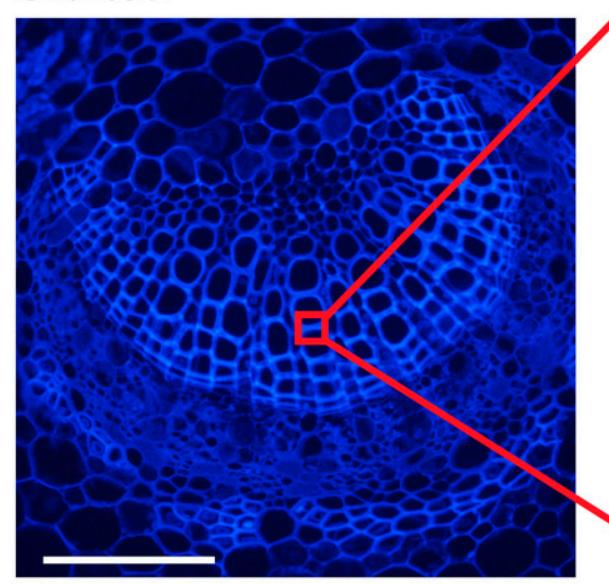

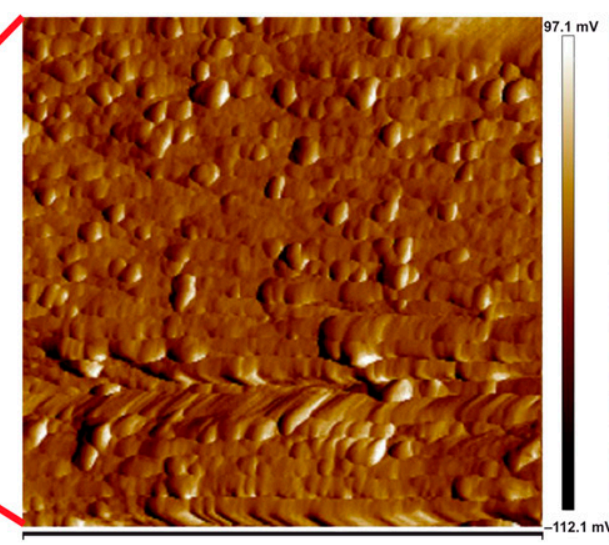

Peak force error

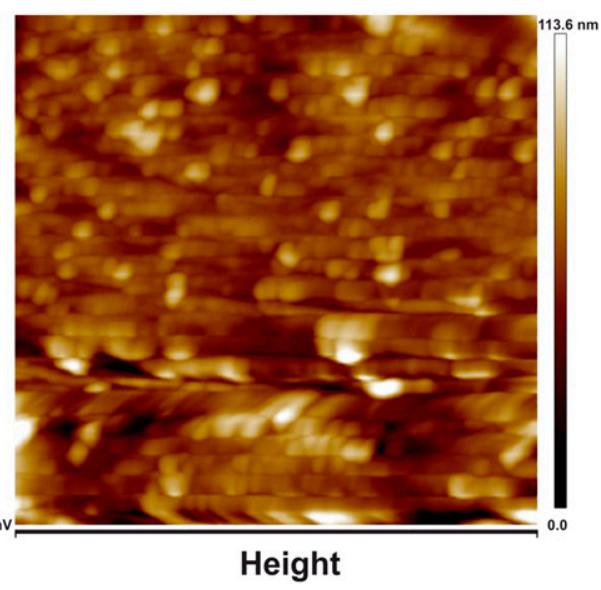

Fig. 4. Lignin autofluorescence images of primary xylem in the leaf midrib (left images), atomic force microscopy (AFM) peak force error images (middle images) and AFM flatten height images (right images) of neighboring cell wall surfaces of the tracheary elements. Scale bars for the micropropagated plants of the dutch elm hybrid 'Dodoens': $50 \mu \mathrm{m}$ for the fluorescence microscopy image, and $2.0 \mu \mathrm{m}$ for AFM images. Scale bars for the grafts of 'Dodoens': $50 \mu \mathrm{m}$ for the fluorescence microscopy image, and $2.2 \mu \mathrm{m}$ for AFM images.

Table 3. Gas exchange and chlorophyll index in the dutch elm hybrid 'Dodoens'.

\begin{tabular}{|c|c|c|c|}
\hline \multirow[b]{3}{*}{ Trait $^{z}$} & \multicolumn{2}{|c|}{ Stock type } & \multirow[b]{3}{*}{$P$ value } \\
\hline & Micropropagated & Grafted & \\
\hline & \multicolumn{2}{|c|}{$($ mean $\pm \mathrm{SE})$} & \\
\hline$P_{\mathrm{N}}\left(\mu \mathrm{mol} \cdot \mathrm{m}^{-2} \cdot \mathrm{s}^{-1}\right)$ & $14.2 \pm 0.1$ & $19.4 \pm 0.3$ & $0.0001 * * *$ \\
\hline$E\left(\mathrm{mmol} \cdot \mathrm{m}^{-2} \cdot \mathrm{s}^{-1}\right)$ & $2.38 \pm 0.02$ & $3.75 \pm 0.09$ & $0.0001 * * *$ \\
\hline$g_{\mathrm{S}}\left(\mathrm{mmol} \cdot \mathrm{m}^{-2} \cdot \mathrm{s}^{-1}\right)$ & $273 \pm 5$ & $392 \pm 17$ & $0.0001 * * *$ \\
\hline$C_{\mathrm{i}}\left(\mu \mathrm{mol} \cdot \mathrm{mol}^{-1}\right)$ & $254 \pm 1$ & $253 \pm 2$ & $0.8332^{\mathrm{Ns}}$ \\
\hline $\mathrm{WUE}_{\text {inst }}\left(\mu \mathrm{mol} \cdot \mathrm{mmol}^{-1}\right)$ & $5.70 \pm 0.05$ & $5.56 \pm 0.08$ & $0.0489 *$ \\
\hline CHLI & $12.8 \pm 0.3$ & $11.0 \pm 0.4$ & $0.0001 * * *$ \\
\hline
\end{tabular}

${ }^{\mathrm{z}} P_{\mathrm{N}}=$ net photosynthetic rate; $E=$ transpiration; $g_{\mathrm{S}}=$ stomatal conductance; $C_{\mathrm{i}}=$ intercellular $\mathrm{CO}_{2}$ concentration; WUE $\mathrm{WU}_{\mathrm{ins}}=$ instantaneous water-use efficiency; CHLI = chlorophyll index.

NS, *, ***Nonsignificant or significant at $P<0.05$ or 0.001 , respectively, based on nested analysis of variance.

$56 \%$ of the variation in $A\left[R^{2}=0.56\right.$ (Fig. 3A)]. Tracheary element lumen area strongly affects the capacity of xylem tissue to conduct water, whereas conduit density influences bulk xylem composition (Preston et al., 2006). The traits $A$ and
$N$ are negatively correlated across angiosperms as well as gymnosperms (Sperry et al., 2008; Zanne et al., 2010). Differences in vascular anatomy and hydraulic conductivity among the rootstocks used for grafting can often play a role in the subsequent vascular growth of a scion. Changes in vessel lumen areas over time in the graft union of various Prunus avium heterograft and homograft combinations were reported by Olmstead et al. (2006). The authors found that the woundrelated callus formation response after grafting led to reduced vessel lumen areas in scion and graft union tissues. In this study, differences found between the stock types for vascular traits $(N$, $F$, and $S$ ) were phenotypically expressed in leaf midribs. This suggests that the differences in leaf vascular performances might be attributed to the rootstock. In some cases, the effect of the rootstock was found to be responsible for the physiological alterations in water transport efficiencies and hydraulic conductance; e.g., in grafted Malus domestica (Cohen and Naor, 2002) or Cucumis melo plants (Agele and Cohen, 2009). However, in this study RC per unit area of the primary xylem tissue did not seem to be affected by the propagation technique.

DiFFERENCES IN MOE OF TRACHEARY ELEMENT CELL WALLS. The tracheary elements of micropropagated plants had stiffer 


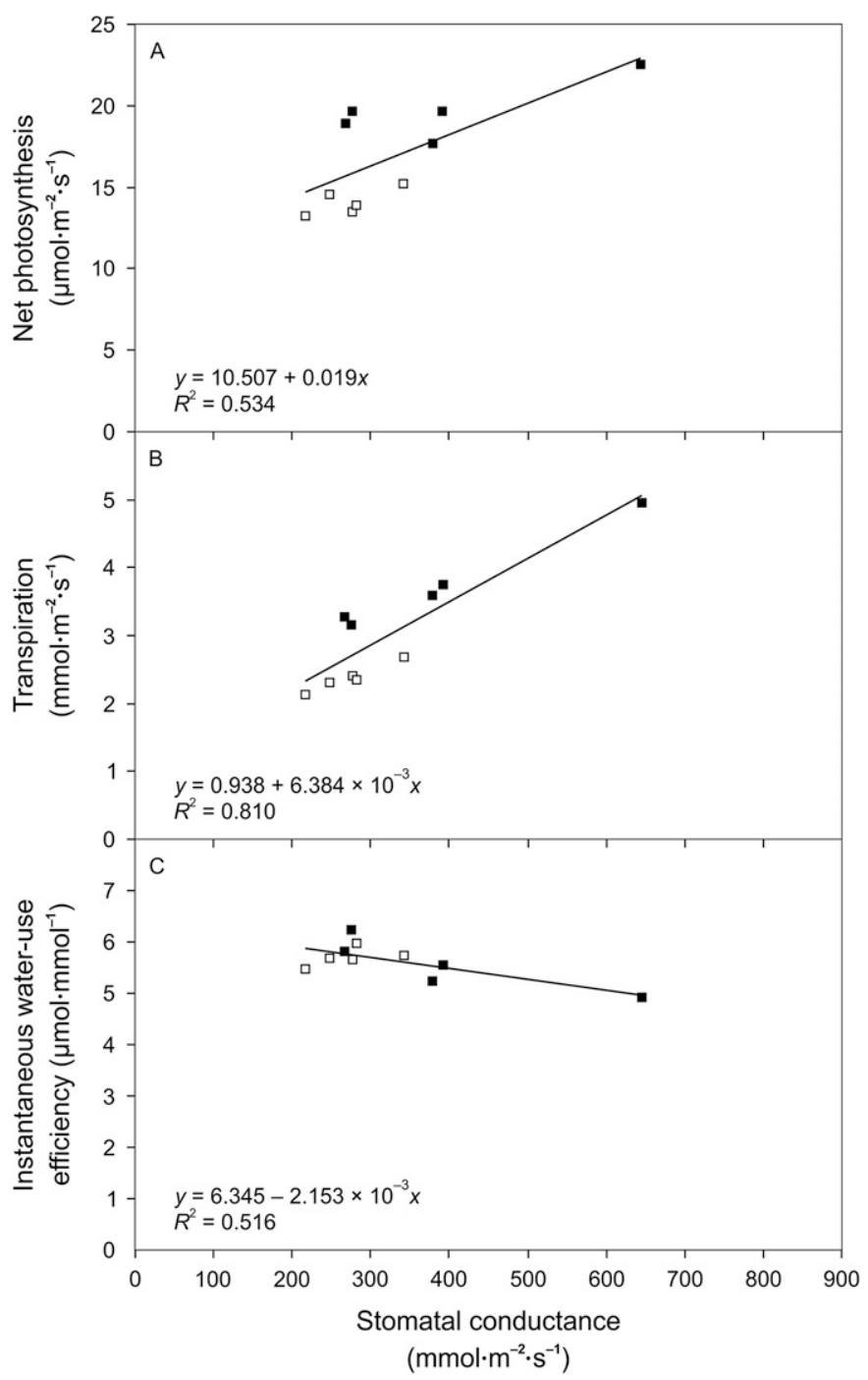

Fig. 5. Trait linkages with stomatal conductance $\left(g_{\mathrm{S}}\right)$ identified in the dutch elm hybrid 'Dodoens'. (A) Relationship of $g_{\mathrm{S}}$ to net photosynthetic rate. (B) Relationship of $g_{\mathrm{S}}$ to transpiration rate. (C) Relationship of $g_{\mathrm{S}}$ to instantaneous water-use efficiency. Open squares show the micropropagated plants, filled squares show the grafts $(n=10)$.

cell walls quantified by MOE (Table 2). In addition, MOE was positively related to the number of tracheary elements per unit area $(r=0.66, P=0.036)$. Measurements of $N$ explained $44 \%$ of the variation in MOE $\left[R^{2}=0.44\right.$ (Fig. 3B)]. From a mechanical point of view, a significant increase in $N$ in the micropropagated plants was accompanied by a significant increase in MOE of cell walls to render a greater stiffness for the primary xylem tissue (Durkovič et al., 2013). Thus, the micropropagated plants may benefit directly from a higher MOE over the grafts by having a reduced risk of tracheary element implosion when an embolism spreads and cavitation of the water column occurs as a result of the stressful conditions caused by $O$. novo-ulmi, the causative agent of DED (Martín et al., 2009, 2010; Ouellette et al., 2004). However, the reasons why the grafts had less stiff cell walls than the micropropagated plants are not completely clear. In our previous study (Durkovič et al., 2015), we found that rootstock significantly affected the relative amounts of lignin and holocellulose as well as neutral saccharides (mainly D-glucose and D-xylose) in the stems of 'Dodoens' grafts. In
Table 4. Chlorophyll $a$ fluorescence in the dutch elm hybrid 'Dodoens' determined on adaxial and abaxial leaf surfaces.

\begin{tabular}{|c|c|c|c|}
\hline \multirow[b]{3}{*}{ Trait $^{\mathrm{z}}$} & \multicolumn{2}{|c|}{ Stock type } & \multirow[b]{3}{*}{$P$ value } \\
\hline & Micropropagated & Grafted & \\
\hline & \multicolumn{2}{|c|}{$($ mean $\pm \mathrm{SE})$} & \\
\hline \multicolumn{4}{|l|}{ Adaxial surface } \\
\hline$F_{\mathrm{v}} / F_{\mathrm{m}}$ & $0.786 \pm 0.003$ & $0.749 \pm 0.004$ & $0.0001 * * *$ \\
\hline$F_{\mathrm{v}} / F_{0}$ & $3.63 \pm 0.07$ & $3.02 \pm 0.07$ & $0.0001^{* * *}$ \\
\hline "Area" $\left(\mathrm{Mb} \cdot \mathrm{s}^{-1}\right)$ & $32.80 \pm 0.78$ & $24.38 \pm 0.69$ & $0.0001^{* * *}$ \\
\hline \multicolumn{4}{|l|}{ Abaxial surface } \\
\hline$F_{\mathrm{v}} / F_{\mathrm{m}}$ & $0.794 \pm 0.003$ & $0.768 \pm 0.003$ & $0.0001 * * *$ \\
\hline$F_{\mathrm{v}} / F_{0}$ & $3.88 \pm 0.06$ & $3.34 \pm 0.05$ & $0.0001 * * *$ \\
\hline "Area" $\left(\mathrm{Mb} \cdot \mathrm{s}^{-1}\right)$ & $24.36 \pm 0.74$ & $20.98 \pm 1.17$ & $0.0098^{* *}$ \\
\hline
\end{tabular}

${ }^{\mathrm{z}} F_{\mathrm{v}}=$ variable fluorescence yield in the dark-adapted state; $F_{\mathrm{m}}=$ maximal fluorescence yield; $F_{\mathrm{v}} / F_{\mathrm{m}}=$ maximum photochemical efficiency of photosystem II; $F_{0}=$ minimal fluorescence yield; $F_{\mathrm{v}} / F_{0}=$ variable-to-initial fluorescence ratio; "Area" = potential electron acceptor capacity of photosystem II.

$* *$, ***Significant at $P<0.01$ or 0.001 , respectively, based on nested analysis of variance.

addition, do Nascimento et al. (2011) reported different relative amounts of sucrose in latex samples of mature Hevea brasiliensis trees which were grafted onto various rootstocks. Gonçalves et al. (2006) found that the concentration of several leaf metabolites such as starch, total phenolics, total chlorophyll, and total carotenoids, was influenced by the rootstock genotype in grafted $P$. avium trees. The above studies indicate the direct effect of the rootstock on the relative amounts of cell wall biopolymers and metabolites in both the stem and the leaves of a scion. Thus, alterations in the content and distribution of cell wall biopolymers might be one of the major reasons for the differences in both MOE and the cell wall deformation discovered between the grafts and the micropropagated plants in this study.

The other nanomechanical traits that are related to the adhesive properties of the cell wall surface; i.e., $\mathrm{ADH}_{\mathrm{ref}}$ and energy dissipation, did not differ significantly according to the propagation technique (Table 2). The quantitative AFM imaging of tracheary element cell walls is shown in Fig. 4. These images show the structure of the cell wall fragment surface in the peak force error and the height AFM channels. The peak force error channel produces a map of the peak force for each pixel in the image during the scan, and reveals the difference between the setpoint and the actual imaging force value. This error-signal provides a sensitive detection technique for the visualization of fine cell wall surface details. The height channel shows a height profile (i.e., cell wall topography).

DIFFERENCES IN ECOPHYSIOLOGICAL TRAITS AND THICKNESS OF LEAF TISSUES. Most of the ecophysiological traits assessed varied according to the applied propagation technique (Table 3 ). The micropropagated plants reached higher values for both WUE $_{\text {inst }}$ and CHLI, whereas the grafts had higher values for $P_{\mathrm{N}}, E$, and $g_{\mathrm{S}}$. No difference between the stock types was found for $C_{\mathrm{i}}$. The measurements of $g_{\mathrm{S}}$ revealed that the grafts were subjected to a less sensitive stomatal regulation of photosynthesis and transpiration than were their micropropagated counterparts. A higher $g_{\mathrm{S}}$ increased carbon uptake during photosynthesis $[r=0.73, P=0.016$ (Fig. 5A)]. Measurements of $g_{\mathrm{S}}$ explained $53 \%$ of the variation in $P_{\mathrm{N}}\left(R^{2}=0.53\right)$ indicating that a smaller proportion in variation was left for the nonstomatal component of photosynthesis. A higher $g_{\mathrm{S}}$ also 
supported a higher rate of $E[r=0.90, P<0.001$ (Fig. 5B) $]$, and measurements of $g_{\mathrm{S}}$ explained $81 \%$ of the variation in $E\left(R^{2}=\right.$ $0.81)$. In addition, $g_{\mathrm{S}}$ was negatively linked with $\mathrm{WUE}_{\mathrm{inst}}$ (Renninger et al., 2015) when individuals conserving water in leaves through a lower $g_{\mathrm{S}}$ had an increased value of $\mathrm{WUE}_{\text {inst }}$ $[r=-0.72, P=0.019$ (Fig. 5C)]. Previous studies have shown that $g_{\mathrm{S}}$ plays a pivotal role in predicting carbon and water exchange between the atmosphere and terrestrial plants (Cernusak et al., 2009; Lin et al., 2015; Orchard et al., 2010). When interpreting the differences in the gas exchange results, one should note that the type of propagation technique also affects the degree of rejuvenation in the planting stock (Bonga and von Aderkas, 1992; Tetsumura et al., 2004). In U. glabra, Durkovič et al. (2010) reported a lesser degree of rejuvenation, accompanied with an earlier onset of flowering and seed production, for the grafts than for the micropropagated plants. The authors observed a similar pattern to that described in this study; i.e., with higher rates of gas exchange (especially $P_{\mathrm{N}}$ ) for the $U$. glabra grafts than for the micropropagated plants. It seems that in vitro micropropagated plants are subjected to a greater degree of rejuvenation, which in turn affects the stomatal regulation of photosynthesis in a more sensitive way than in the grafts. It may, thus, be a reason why the micropropagated plants obtained lower photosynthesis than the grafts. Our results confirmed that stomatal behavior was an important regulator of gas exchange and water use for both the micropropagated and grafted plants of 'Dodoens'. It could be assumed that due to a higher photosynthetic carbon gain per unit transpirational water vapor loss found in the micropropagated plants, this stock type could have a higher acclimation capacity to stressful environmental conditions than the grafts. This assumption was supported by additional data coming from chlorophyll $a$ fluorescence yields (see below).

The micropropagated plants reached significantly higher values for $F_{\mathrm{v}} / F_{\mathrm{m}}, F_{\mathrm{v}} / F_{0}$, and potential electron acceptor capacity than the grafts for both leaf surfaces (Table 4). For both stock types, higher values of $F_{\mathrm{v}} / F_{\mathrm{m}}$ and $F_{\mathrm{v}} / F_{0}$ ratios were recorded for abaxial than for adaxial surfaces, whereas the contrary was true for the variable "area." Typically, for nonstressed plants a characteristic $F_{\mathrm{v}} / F_{\mathrm{m}}$ ratio of open photosystem II is in the range of $0.75-0.85$. A rapid decline in $F_{\mathrm{v}} / F_{\mathrm{m}}$ is a sensitive and early indicator of a change in photosynthesis and in the physiological status of the plant in general (BolhàrNordenkampf et al., 1989). Measurements in this study revealed that $F_{\mathrm{v}} / F_{\mathrm{m}}$ ratio for the grafts reached an average value of 0.759 as opposed to 0.790 for the micropropagated plants. Thus, the reaction centers of photosystem II were functionally intact irrespective of the propagation technique. Moreover, their $F_{\mathrm{v}} / F_{\mathrm{m}}$ ratios were far higher than the threshold value of 0.725 which indicates the onset of reversible changes in the reaction centers of photosystem II (Čaňová et al., 2012). The variable $F_{\mathrm{v}} / F_{0}$ estimates the maximum primary yield of photochemistry of photosystem II. A decline in $F_{\mathrm{v}} / F_{0}$ ratio has been used as an indicator of drought stress (Li et al., 2006; Percival and Sheriffs, 2002). The variable "area" determines the potential acceptor capacity for electron transport during the primary processes of photosynthesis and has been shown to be a sensitive indicator of salinity (Panda et al., 2006). Despite lower values found in the grafts, chlorophyll $a$ fluorescence yields were found within an optimum range for both nonstressed stock types.

We also observed several differences in the internal organization of leaf tissues between the stock types. The leaf, mesophyll, palisade parenchyma, and spongy parenchyma of
the grafts had a greater thickness than those of the micropropagated plants

(Table 5). The relationship between
$0.0001 * *$

$0.0010 * * *$

$0.0015^{* *}$

**, ***Significant at $P<0.01$ or 0.001 , respectively, based on nested analysis of variance.

$P$ value

$153.67 \pm 4.62 \quad 168.50 \pm 3.44$

$116.67 \pm 3.76 \quad 134.41 \pm 2.95$

$56.92 \pm 1.79 \quad 65.35 \pm 2.24$

$59.75 \pm 2.63$

$69.05 \pm 2.14$

Palisade parenchyma thickness $(\mu \mathrm{m})$
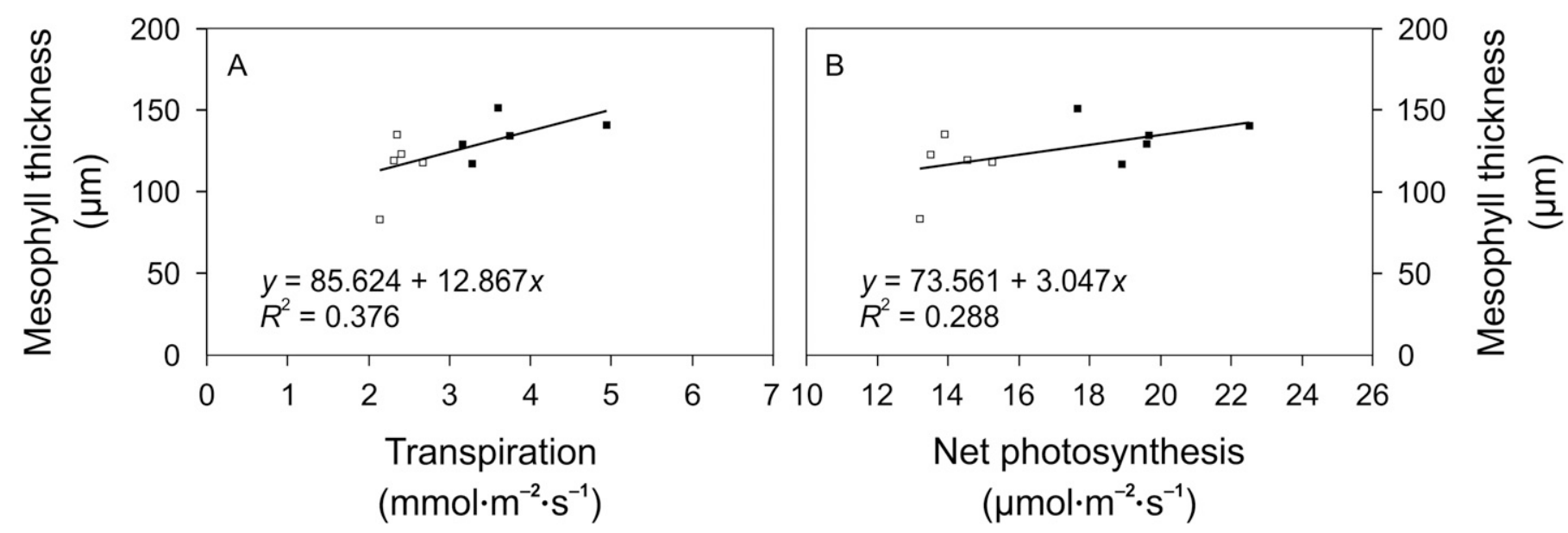

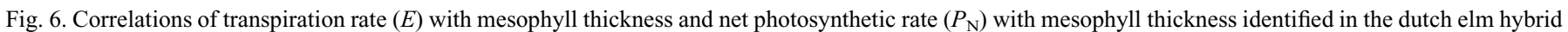
'Dodoens'. (A) Relationship of $E$ to mesophyll thickness. (B) Relationship of $P_{\mathrm{N}}$ to mesophyll thickness. Open squares show the micropropagated plants, filled squares show the grafts $(\mathrm{n}=10)$. 


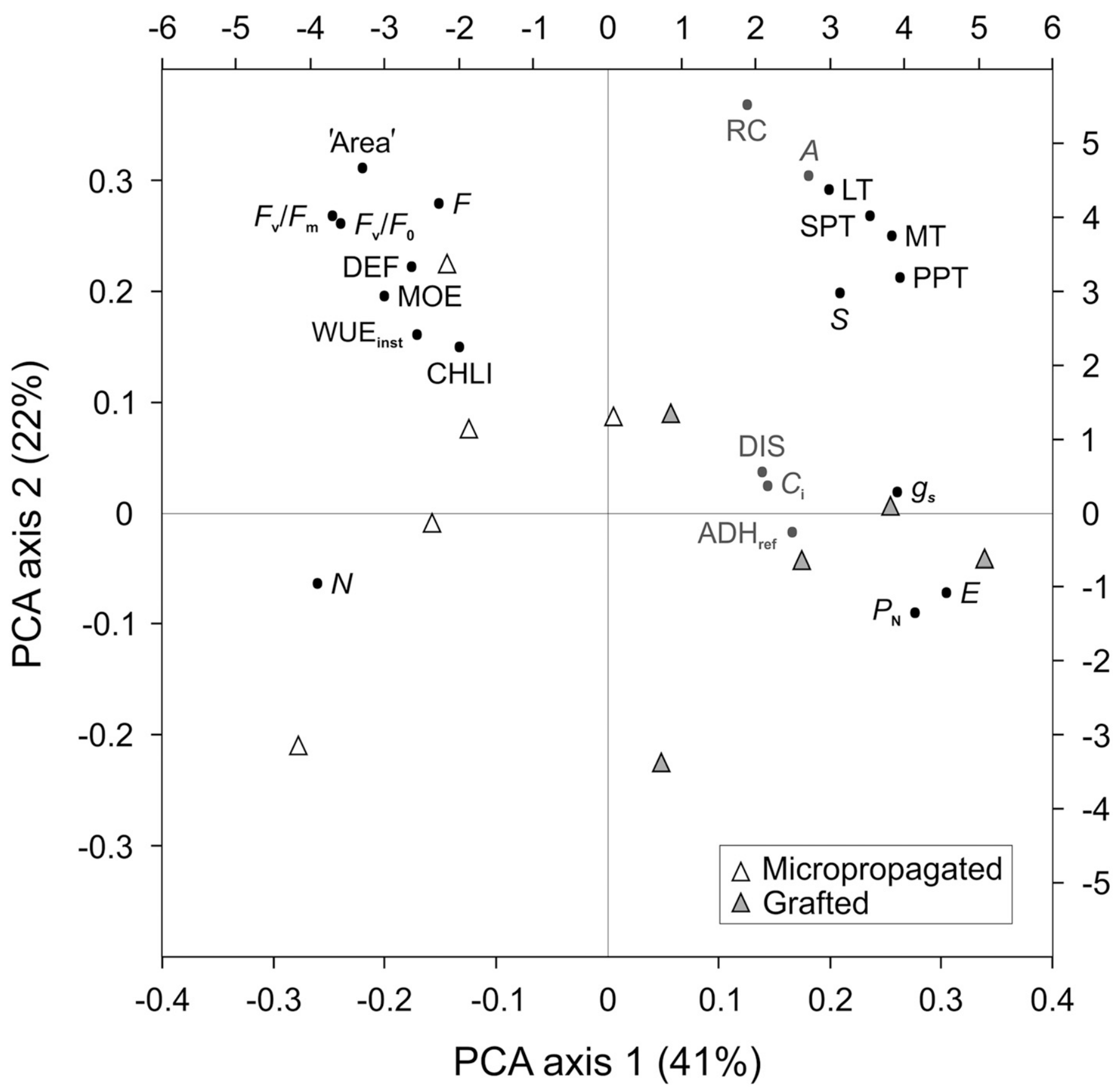

Fig. 7. Positions of 22 leaf traits on the first and second axes of the principal component analysis (PCA). Traits associated with nonsignificant differences between the micropropagated plants and the grafts are indicated in gray. The bottom and left-hand axes refer to the examined leaf traits, whereas the top and right-hand axes refer to the examined trees; $A=$ tracheary element lumen area, $\mathrm{ADH}_{\text {ref }}=$ adhesion at the reference tip end radius, "area" = potential electron acceptor capacity of photosystem II, $C_{\mathrm{i}}=$ intercellular $\mathrm{CO}_{2}$ concentration, $\mathrm{CHLI}=$ chlorophyll index, DEF = deformation, DIS = energy dissipation, $E=$ transpiration, $F=$ tracheary element lumen fraction, $F_{\mathrm{v}} / F_{\mathrm{m}}=$ maximum photochemical efficiency of photosystem II, $F_{\mathrm{v}} / F_{0}=$ variable-to-initial fluorescence ratio, $g_{\mathrm{S}}=$ stomatal conductance, $\mathrm{LT}=$ leaf thickness, $\mathrm{MOE}=$ reduced Young's modulus of elasticity, MT = mesophyll thickness, $N=$ number of tracheary elements per $0.1 \mathrm{~mm}^{2}$ of the primary xylem area, $P_{\mathrm{N}}=$ net photosynthetic rate, $\mathrm{PPT}=$ palisade parenchyma thickness, $S=$ tracheary element size:number ratio, $\mathrm{SPT}=$ spongy parenchyma thickness, $\mathrm{RC}$ $=$ relative conductivity per $0.1 \mathrm{~mm}^{2}$ of the primary xylem area, $\mathrm{WUE}_{\mathrm{inst}}=$ instantaneous water-use efficiency. The micropropagated plants and the grafts of the dutch elm hybrid 'Dodoens' are as indicated in the key.

mesophyll thickness and $E$ was marginally significant $[r=0.61$, $P=0.059$ (Fig. 6A)], whereas the linkage between mesophyll thickness and carbon uptake $\left(P_{\mathrm{N}}\right)$ was nonsignificant $[r=0.54$, $P=0.110$ (Fig. 6B)]. Thus, the increased mesophyll thickness apparent in the grafts might have benefited from a higher transpiration rate; i.e., a higher mass flow of mineral nutrients and water from roots to the internal tissues in the leaf. In addition, the larger intercellular air spaces due to the increased thickness of the spongy parenchyma could reduce resistance in the mesophyll part of the $\mathrm{CO}_{2}$ diffusion pathway (Pons et al., 2009 ), and thereby indirectly support a higher rate of $P_{\mathrm{N}}$, especially in the grafts. 
Associations among Leaf traits. A PCA was done to evaluate how the examined leaf traits were associated (Fig. 7). The first axis explained $41 \%$ of the variation and showed strong positive loadings for $E, P_{\mathrm{N}}, g_{\mathrm{S}}$, and the thickness of palisade parenchyma, spongy parenchyma, and mesophyll. The negative side of the axis indicated strong loadings for $N$, and chlorophyll $a$ fluorescence yields $F_{\mathrm{v}} / F_{\mathrm{m}}, F_{\mathrm{v}} / F_{0}$, and "area." The second axis explained $22 \%$ of the variation and showed strong positive loadings for RC, "area," $A, F$, and the thickness of the leaf. The negative side of the axis indicated loadings for $P_{\mathrm{N}}, E, N$, and

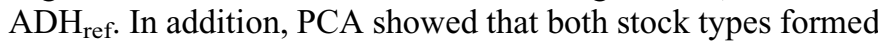
compact homogeneous clusters clearly separated from each other in the multivariate leaf trait analysis, except for a single specimen from the micropropagated group of plants. This specimen was positioned in very close proximity to the cluster belonging to the grafts. Distributions of the micropropagated plants showed a lesser variation in the first PCA axis (which explained a major portion of the overall variation) and a greater variation in the second PCA axis. The grafts responded conversely, with a greater variation in the first PCA axis and a lesser variation in the second PCA axis.

\section{Summary}

The results presented here show that several leaf midrib vascular traits $(N, F, S)$, MOE, cell wall deformation, as well as ecophysiological and anatomical traits (gas exchange, chlorophyll $a$ fluorescence, and thickness of leaf tissues) varied according to the technique used for clonal propagation of the dutch elm hybrid 'Dodoens'. The effect of the rootstock might contribute to the differences in vascular traits, as well as to the differences in cell wall stiffness and cell wall deformation observed between the stock types. The higher values of both WUE $_{\text {inst }}$ and chlorophyll $a$ fluorescence found in the micropropagated plants indicate a higher acclimation capacity to stressful environmental conditions specifically for this stock type. Taken together, the micropropagated plants reached significantly higher values for nine traits (40.9\%), including chlorophyll $a$ fluorescence yields and indicators of leaf vascular architecture such as $N$ and $F$. The grafts reached higher values for eight traits $(36.4 \%)$, primarily associated with gas exchange, the thickness of the leaf, mesophyll, palisade and spongy parenchyma, as well as for vascular trait $S$. Similarities between the stock types were found for five traits $(22.7 \%)$.

\section{Literature Cited}

Agele, S. and S. Cohen. 2009. Effect of genotype and graft type on the hydraulic characteristics and water relations of grafted melon. J. Plant Interact. 4:59-66.

Amitay-Sadovsky, E., B. Ward, G.A. Somorjai, and K. Komvopoulos. 2002. Nanomechanical properties and morphology of thick polyurethane films under contact pressure and stretching. J. Appl. Phys. 91:375-381.

Benowicz, A., S.C. Grossnickle, and Y.A. El-Kassaby. 2002. Field assessment of douglas-fir somatic and zygotic seedlings with respect to gas exchange, water relations, and frost hardiness. Can. J. For. Res. 32:1822-1828.

Berger, S., Z. Benediktyová, K. Matouš, K. Bonfig, M.J. Mueller, L. Nedbal, and T. Roitsch. 2007. Visualization of dynamics of plantpathogen interaction by novel combination of chlorophyll fluorescence imaging and statistical analysis: Differential effects of virulent and avirulent strains of $P$. syringae and of oxylipins on $A$. thaliana. $\mathrm{J}$. Expt. Bot. 58:797-806.
Biroščíková, M., K. Spišáková, Š. Lipták, V. Pichler, and J. Durkovič. 2004. Micropropagation of mature wych elm (Ulmus glabra Huds.). Plant Cell Rpt. 22:640-644.

Bolhàr-Nordenkampf, H.R., S.P. Long, N.R. Baker, G. Öquist, U. Schreiber, and E.G. Lechner. 1989. Chlorophyll fluorescence as a probe of the photosynthetic competence of leaves in the field: A review of current instrumentation. Funct. Ecol. 3:497-514.

Bonga, J.M. and P. von Aderkas. 1992. In vitro culture of trees. Kluwer Academic Publ., Dordrecht, The Netherlands.

Brasier, C.M. 1991. Ophiostoma novo-ulmi sp. nov., causative agent of current dutch elm disease pandemics. Mycopathologia 115:151-161.

Brito, G., A. Costa, C. Coelho, and C. Santos. 2009. Large-scale field acclimatization of Olea maderensis micropropagated plants: Morphological and physiological survey. Trees 23:1019-1031.

Campbell, D.R., C. Galen, and C.A. Wu. 2005. Ecophysiology of first and second generation hybrids in a natural plant hybrid zone. Oecologia 144:214-225.

Čaňová, I., J. Durkovič, D. Hladká, and I. Lukáčik. 2012. Changes in stomatal characteristics and photochemical efficiency during leaf development in six species of Sorbus. Photosynthetica 50:635-640.

Carvalho, L.C., M.L. Osório, M.M. Chaves, and S. Amâncio. 2001. Chlorophyll fluorescence as an indicator of photosynthetic functioning of in vitro grapevine and chestnut plantlets under ex vitro acclimatization. Plant Cell Tissue Organ Cult. 67:271-280.

Cassol, D., F.S.P. De Silva, A.R. Falqueto, and M.A. Bacarin. 2008. An evaluation of non-destructive methods to estimate total chlorophyll content. Photosynthetica 46:634-636.

Cernusak, L.A., K. Winter, J. Aranda, A. Virgo, and M. Garcia. 2009. Transpiration efficiency over an annual cycle, leaf gas exchange and wood carbon isotope ratio of three tropical tree species. Tree Physiol. 29:1153-1161.

Cohen, S. and A. Naor. 2002. The effects of three rootstocks on water use, canopy conductance and hydraulic parameters of apple trees and predicting canopy from hydraulic conductance. Plant Cell Environ. $25: 17-28$.

Conde, P., A. Sousa, A. Costa, and C. Santos. 2008. A protocol for Ulmus minor Mill. micropropagation and acclimatization. Plant Cell Tissue Organ Cult. 92:113-119.

Corredoira, E., A.M. Vieitez, and A. Ballester. 2002. Somatic embryogenesis in elm. Ann. Bot. 89:637-644.

Derjaguin, B.V., V.M. Muller, and Y.P. Toporov. 1975. Effect of contact deformations on the adhesion of particles. J. Colloid Interface Sci. 53:314-326.

Desotgiu, R., M. Pollastrini, C. Cascio, G. Gerosa, R. Marzuoli, and F. Bussotti. 2012. Chlorophyll $a$ fluorescence analysis along a vertical gradient of the crown in a poplar (Oxford clone) subjected to ozone and water stress. Tree Physiol. 32:976-986.

do Nascimento, E.S.P., C.R. de Oliveira, P. de Souza Gonçalves, R.B. da Costa, R.M.B. Moreno, L.H.C. Mattoso, and A.G. Ferreira. 2011. Effect of rootstock on the scion of Hevea brasiliensis through metabolic analysis of latex samples by ${ }^{1} \mathrm{H}$ NMR. Crop Breeding Appl. Biotechnol. 11(S1):82-88.

Dufrêne, Y.F., D. Martínez-Martín, I. Medalsy, D. Alsteens, and D.J. Müller. 2013. Multiparametric imaging of biological systems by force-distance curve-based AFM. Nature Methods 10:847-854.

Ďurkovič, J., I. Čaňová, R. Lagaňa, V. Kučerová, M. Moravčík, T. Priwitzer, J. Urban, M. Dvořák, and J. Krajňáková. 2013. Leaf trait dissimilarities between Dutch elm hybrids with a contrasting tolerance to dutch elm disease. Ann. Bot. 111:215-227.

Ďurkovič, J., I. Čaňová, T. Priwitzer, M. Biroščíková, P. Kapral̆, and M. Saniga. 2010. Field assessment of photosynthetic characteristics in micropropagated and grafted wych elm (Ulmus glabra Huds.) trees. Plant Cell Tissue Organ Cult. 101:221-228.

Durkovič, J., F. Kačík, M. Mamoňová, M. Kardošová, R. Longauer, and J. Krajňáková. 2015. The effects of propagation techniques on cell wall chemistry and wood anatomy in micropropagated and grafted plants of the dutch elm hybrid 'Dodoens'. J. Amer. Soc. Hort. Sci. 140:3-11. 
Ďurkovič, J., F. Kačík, D. Olčák, V. Kučerová, and J. Krajňáková. 2014. Host responses and metabolic profiles of wood components in Dutch elm hybrids with a contrasting tolerance to Dutch elm disease. Ann. Bot. 114:47-59.

Duurkovič, J., M. Kardošová, I. Čaňová, R. Lagaňa, T. Priwitzer, D. Chorvát, Jr., A. Cicák, and V. Pichler. 2012. Leaf traits in parental and hybrid species of Sorbus (Rosaceae). Amer. J. Bot. 99:14891500.

Ďurkovič, J. and A. Mišalová. 2009. Wood formation during ex vitro acclimatisation in micropropagated true service tree (Sorbus domestica L.). Plant Cell Tissue Organ Cult. 96:343-348.

Eshita, S.M., J.C. Kamalay, V.M. Gingas, and D.A. Yaussy. 2000. Establishment and characterization of American elm cell suspension cultures. Plant Cell Tissue Organ Cult. 61:245-249.

Fenning, T.M., K.M.A. Gartland, and C.M. Brasier. 1993. Micropropagation and regeneration of English elm, Ulmus procera Salisbury. J. Expt. Bot. 44:1211-1217.

Fischer-Cripps, A.C. 2011. Nanoindentation. 3rd ed. Springer, New York, NY.

Gerhold, H.D. 1970. A decade of progress in breeding disease-resistant forest trees. Unasylva 24:37-44.

Gonçalves, B., J. Moutinho-Pereira, A. Santos, A.P. Silva, E. Bacelar, C. Correia, and E. Rosa. 2006. Scion-rootstock interaction affects the physiology and fruit quality of sweet cherry. Tree Physiol. 26:93104.

Green, C.E., R.P. Guries, and E.B. Smalley. 1985. Early screening of elms for resistance to Ceratocystis ulmi. Plant Dis. 69:60-63.

Harvengt, L., A. Meier-Dinkel, E. Dumas, and E. Collin. 2004. Establishment of a cryopreserved gene bank of European elms. Can. J. For. Res. 34:43-55.

Hiemstra, J.A., J. Buiteveld, J. Kopinga, K.G. Kranenborg, M.B.M. Ravesloot, B.J. van der Sluis, and S.M.G. de Vries. 2006. Belang en toekomst van de iep in Nederland. Plant \& Omgeving, Wageningen, The Netherlands.

Janmey, P.A., J.P. Winer, M.E. Murray, and Q. Wen. 2009. The hard life of soft cells. Cell Motil. Cytoskeleton 66:597-605.

Krajňáková, J. and R. Longauer. 1996. Culture initiation, multiplication and identification of in vitro regenerants of resistant hybrid elms. Lesnictví-Forestry 42:261-270.

Li, R.-h., P.-g. Guo, M. Baum, S. Grando, and S. Ceccarelli. 2006. Evaluation of chlorophyll content and fluorescence parameters as indicators of drought tolerance in barley. Agr. Sci. China 5:751-757.

Lin, Y.-S., B.E. Medlyn, R.A. Duursma, I.C. Prentice, H. Wang, S. Baig, D. Eamus, V.R. de Dios, P. Mitchell, D.S. Ellsworth, M.O. de Beeck, G. Wallin, J. Uddling, L. Tarvainen, M.-L. Linderson, L.A. Cernusak, J.B. Nippert, T.W. Ocheltree, D.T. Tissue, N.K. MartinStPaul, A. Rogers, J.M. Warren, P. De Angelis, K. Hikosaka, Q. Han, Y. Onoda, T.E. Gimeno, C.V.M. Barton, J. Bennie, D. Bonal, A. Bosc, M. Löw, C. Macinins-Ng, A. Rey, L. Rowland, S.A. Setterfield, S. Tausz-Posch, J. Zaragoza-Castells, M.S.J. Broadmeadow, J.E. Drake, M. Freeman, O. Ghannoum, L.B. Hutley, J.W. Kelly, K. Kikuzawa, P. Kolari, K. Koyama, J.-M. Limousin, P. Meir, A.C.L. da Costa, T.N. Mikkelsen, N. Salinas, W. Sun, and L. Wingate. 2015. Optimal stomatal behaviour around the world. Nature Clim. Change 5:459-464.

Martín, J.A., A. Solla, L.G. Esteban, P. de Palacios, and L. Gil. 2009. Bordered pit and ray morphology involvement in elm resistance to Ophiostoma novo-ulmi. Can. J. For. Res. 39:420-429.

Martín, J.A., A. Solla, L. Gil, and M.C. García-Vallejo. 2010. Phenological and histochemical changes of Ulmus minor due to root absorption of phenol: Implications for resistance to DED. Environ. Expt. Bot. 69:175-182.

Martín, J.A., A. Solla, M. Venturas, C. Collada, J. Domínguez, E. Miranda, P. Fuentes, M. Burón, S. Iglesias, and L. Gil. 2015. Seven Ulmus minor clones tolerant to Ophiostoma novo-ulmi registered as forest reproductive material in Spain. iForest 8:172-180.
Merkle, S.A., G.M. Andrade, S.J. Nairn, W.A. Powell, and C.A. Maynard. 2007. Restoration of threatened species: A noble cause for transgenic trees. Tree Genet. Genomes 3:111-118.

Mezzetti, B., G. Minotta, O. Navacchi, and P. Rosati. 1988. In vitro propagation of Ulmus carpinifolia. Acta Hort. 227:396-398.

Newhouse, A.E., F. Schrodt, H. Liang, C.A. Maynard, and W.A. Powell. 2007. Transgenic American elm shows reduced Dutch elm disease symptoms and normal mycorrhizal colonization. Plant Cell Rpt. 26:977-987.

Olmstead, M.A., N.S. Lang, F.W. Ewers, and S.A. Owens. 2006. Xylem vessel anatomy of sweet cherries grafted onto dwarfing and nondwarfing rootstocks. J. Amer. Soc. Hort. Sci. 131:577-585.

Orchard, K.A., L.A. Cernusak, and L.B. Hutley. 2010. Photosynthesis and water-use efficiency of seedlings from northern Australian monsoon forest, savanna and swamp habitats grown in a common garden. Funct. Plant Biol. 37:1050-1060.

Ouellette, G.B., D. Rioux, M. Simard, and M. Cherif. 2004. Ultrastuctural and cytochemical studies of host and pathogens in some fungal wilt diseases: Retro- and introspection towards a better understanding of DED. Investigación Agraria Sistemas y Recursos Forestales 13:119-145.

Panda, D., P.K. Dash, N.K. Dhal, and N.C. Rout. 2006. Chlorophyll fluorescence parameters and chlorophyll content in mangrove species grown in different salinity. Gen. Appl. Plant Physiol. 32:175-180.

Percival, G.C. and C.N. Sheriffs. 2002. Identification of droughttolerant woody perennials using chlorophyll fluorescence. J. Arboricult. 28:215-223.

Pfreundschuh, M., D. Martinez-Martin, E. Mulvihill, S. Wegmann, and D.J. Muller. 2014. Multiparametric high-resolution imaging of native proteins by force-distance curve-based AFM. Nature Protoc. 9:1113-1130.

Pletikapić, G., A. Berquand, T. Mišić Radić, and V. Svetličić. 2012. Quantitative nanomechanical mapping of marine diatom in seawater using peak force tapping atomic force microscopy. J. Phycol. 48:174-185.

Plichta, R., J. Urban, R. Gebauer, M. Dvořák, and J. Ďurkovič. 2016. Long-term impact of Ophiostoma novo-ulmi on leaf traits and transpiration of branches in the Dutch elm hybrid 'Dodoens'. Tree Physiol. 36:335-344.

Pons, T.L., J. Flexas, S. von Caemmerer, J.R. Evans, B. Genty, M. Ribas-Carbo, and E. Brugnoli. 2009. Estimating mesophyll conductance to $\mathrm{CO}_{2}$ : Methodology, potential errors, and recommendations. J. Expt. Bot. 60:2217-2234.

Preston, K.A., W.K. Cornwell, and J.L. DeNoyer. 2006. Wood density and vessel traits as distinct correlates of ecological strategy in 51 California coast range angiosperms. New Phytol. 170:807-818.

Ren, D., H. Wang, Z. Yu, H. Wang, and Y. Yu. 2015. Mechanical imaging of bamboo fiber cell walls and their composites by means of peakforce quantitative nanomechanics (PQNM) technique. Holzforschung 69:975-984.

Renninger, H.J., N.J. Carlo, K.L. Clark, and K.V.R. Schäfer. 2015. Resource use and efficiency, and stomatal responses to environmental drivers of oak and pine species in an Atlantic Coastal Plain forest. Front. Plant Sci. 6:297.

Santini, A., F. Pecori, A.L. Pepori, F. Ferrini, and L. Ghelardini. 2010. Genotype $\times$ environment interaction and growth stability of several elm clones resistant to Dutch elm disease. For. Ecol. Mgt. 260:10171025.

Shukla, M.R., A.M. Jones, J.A. Sullivan, C. Liu, S. Gosling, and P.K. Saxena. 2012. In vitro conservation of American elm (Ulmus americana): Potential role of auxin metabolism in sustained plant proliferation. Can. J. For. Res. 42:686-697.

Smalley, E.B. and R.P. Guries. 1993. Breeding elms for resistance to Dutch elm disease. Annu. Rev. Phytopathol. 31:325-352.

Sperry, J.S., F.C. Meinzer, and K.A. McCulloh. 2008. Safety and efficiency conflicts in hydraulic architecture: Scaling from tissues to trees. Plant Cell Environ. 31:632-645. 
Sweers, K., K. van der Werf, M. Bennink, and V. Subramaniam. 2011. Nanomechanical properties of $\alpha$-synuclein amyloid fibrils: A comparative study by nanoindentation, harmonic free microscopy, and Peakforce QNM. Nanoscale Res. Lett. 6:270.

Tetsumura, T., Y. Koyanagi, S. Ito, T. Habu, and K. Kawase. 2004. Comparative field performance of mature Japanese persimmon trees grafted on seedling rootstocks vs. micropropagated ones. J. Jpn. Soc. Hort. Sci. 73:134-136.

Zanne, A.E. and D.S. Falster. 2010. Plant functional traits-linkages among stem anatomy, plant performance and life history. New Phytol. 185:348-351.
Zanne, A.E., M. Westoby, D.S. Falster, D.D. Ackerly, S.R. Loarie, S.E.J. Arnold, and D.A. Coomes. 2010. Angiosperm wood structure: Global patterns in vessel anatomy and their relation to wood density and potential conductivity. Amer. J. Bot. 97:207-215.

Zhao, P., P. Liu, J. Shao, C. Li, B. Wang, X. Guo, B. Yan, Y. Xia, and M. Peng. 2015. Analysis of different strategies adapted by two cassava cultivars in response to drought stress: Ensuring survival or continuing growth. J. Expt. Bot. 66:1477-1488.

Zimmermann, M.H. 1983. Xylem structure and the ascent of sap. Springer-Verlag, Berlin, Germany. 